\title{
University of Shkodra " Luigj Gurakuqi” on university trade
}

\author{
Artan Haxhi \\ Irakli Beka \\ University Shkoder „Luigj Gurakuqi“, Shkoder, Albania \\ ahaxhi@gmail.com \\ bekairakli@yahoo.co
}

DOI:10.5901/mjss.2014.v5n19p270

\begin{abstract}
University of Shkodra "Luigj Gurakuqi" is one of the oldest universities of Albania. There are 15 Public and 44 Private Universities and Schools of Higher Education in Albania. The University of Shkodra was established in 1957. It has 6 faculties attended by more than 15000 students. It issues 24 Bachelor and 43 master diplomas (Professional Master and Master of Science) and PH.D programs. In this material there is given information about the objectives and the strategy of Shkodra University, different relations with many national and international universities with the aim to improve the teaching process, scientific research work as well as a better management of its resources. In the framework of this study it is reflected our experience in the management of university, which has helped us to be competitive in the University trade and "Economy market" according to the high standards of High European Education in Albania and everywhere. In recent years, the strengthening and expansion of the University of Shkodra cooperation with various universities in Europe and USA has helped in improving the level of teaching, scientific management concepts based on new market economy system. Taking into account the idea that education is a good thing for the public, as well as, the fact that today we are at the stage of creating a democratic state and society based on the values, knowledge and prosperity, we can say that higher education has been and remains a key priority for any society, particularly for Albanian society. In this context, the goal of our University is to become a shelter of free thought and responsible promoters of scientific facts. We aim to be competitive in the market, aiming in particular at strengthening the quality of teaching and scientific work. We are aware that the quality and scientific research are the bases that help us in the adaptation and mobility towards European standards of Higher Education. The real situation of development of higher education, with its difficulties and problems, and the recent development trends of the University of Shkodra, have engaged us in adapting and implementing the highest possible standard in community of Albanian and European University work.
\end{abstract}

Keywords: High education, Bologna declaration, Internationalization of university, university trade.

\section{Introduction}

Rapid and continuous technological and economic changes (as well as their consequences for the labour market) in the world today, pose new challenges to higher education in general.

Universities bilateral relations with the labour market and increasing number of students attending higher education institutions place universities in front of the necessity to organize and reorganize their systems of study under to some welldefined academic standards.

Taking into consideration such a situation, we should meet the essential requirements of the diverse offered diplomas by our University.

University of Shkodra "Luigj Gurakuqi" is one of the oldest universities in Albania, with over 57 years experience in Albanian Higher Education. It has six faculties with 24 programs of study "bachelor", 43 programs of study "professional master" and "master of science" and 1 study program "doctoral studies".

The offered study programs at our University prepare specialists who have access to the labour market and they have possibilities to be qualified in different scientific directions or they have also got the professional opportunities in the field of specialization. 
We can say that teaching autonomy has allowed us to determine the content of the courses in accordance to the dynamics of the labour market.

The curricula compilation is designed to gradually improve the level of deployment of graduates in the labour market. This is done by emphasising the instruments of cooperation between universities and the productive economic entities, as well as by consulting with the social partners (different orders and professional colleges, associations).

This requires that universities determine in the curriculum the objectives and formative activities. This should be done after being consulted with the labour market and the representative of organizations in local and regional level.

Based on the current state of development of higher education in Albania and the development trends of the University of Shkodra in particular, our goal is to be engaged and integrated into the higher standard of higher education in Albanian by facing the challenges of competition in the university market.

\section{Main aims of teaching and scientific work in university}

Being in front of these challenges, we stress that some of the main aims of teaching and scientific work in university would be as following:

I. Enlargement and enforcement of the studies in three cycles of studies in different branches at Shkodra University and the continuous growth of the quality of the teaching process - (important factors in preparing qualified specialists not only in the scientific field but also in the practical skills in order to successfully cope with security challenges of working in a market economy). To accomplish this task we need to:

Develop the university studies in three cycles, mainly in those faculties which have the needed qualified academic staff;

Evaluate the programs of study in order to further develop the academic qualities by combining employment opportunities and competition. This would make possible to offer to our students and create much greater employment possibilities in Albanian market;

Renew and continuous improve the curricula, teaching plans and programs meeting the Western European standards;

Create gradual various new profiles and encourage interdisciplinary. But we should study the needs of the labour market before;

Continuous improve and develop the educational and scientific infrastructure in order to facilitate the maximum development of teaching process in order to face the challenges of employment;

Enrich the scientific educational infrastructure through the establishment of new laboratories and scientific teaching;

II. The continuous increase of the scientific work level considering it as highly connected to the didactic activities.

For such a purpose we have to:

clearly define the basic rules of the organization and the management process of scientific research activities. The financial means, income administration and fees for the administrative and scientific entities should be well-planned;

specify the stimulating instruments and policies for the research activities;

stimulate the activity of the existing scientific units and establish new research units at respective faculties;

not to consider the scientific research work as individual work as it has been considered till now but we should consider it as an integral part of department's activities. Research results should raise the quality of teaching service and promote teamwork.

deepen the scientific research activities and increase publications in scientific journals particularly in journals with impact factor;

reconsider the teaching load of the professors according to their scientific research activity;

continuous scientific qualification of academic staff should be considered as important element in the increase of scientific level work at university.

The achievement of these aims requests a stronger cooperation of Shkodra University with different scientific institutions in Albania and other countries. The improvement of the scientific infrastructure in order to give the possibility to the scientific researchers to express their capacities. 
III- The scientific experience in the field of teaching and research through participation in scientific conferences and publishing of scientific articles in national and international journals.

Shkodra University, with a history of over 57 years in the field of higher education in Albania, has gained valuable experience in terms of preparing teachers and different specialists. The experience gained has requested an integration of forms and new ways which help us in developing a standard in teaching process and increases the level of research. It is important that departments and public opinion uses these results.

In the framework of this goal, there are organised many scientific activities in cooperation with various national or international scientific institutions or our professors have participated in these activities in different European countries. In these activities there are addressed and discussed economic, social, environmental, cultural and regional issues regarding the field of higher education.Many of these results have been published in various scientific journals at national or international level targeting those with impact factor.

The increased number of the articles published shows a greater commitment of the academic staff in the field of research in the respective disciplines. There is noted an increasing number of young professors engaged in research.

\section{IV.The Internationalization through the strengthening of international relations.}

We aim to:

- develop the exchange of students and researchers among universities, especially with American and European Universities, in order to enable the establishment of relationships as positive recognition and a mutual objective assessment of the work. Researchers at the universities of different countries have common interests study. In many cases they can approach to each - other on the basis of an inter-institutional program to perform additional studies and results of joint publications.

- strengthen efforts for a further qualification of the staff in various areas, such as academic, technical - scientific and administrative managerial;

- collaboration with universities across Europe create a huge potential and fruitful cooperation, based on interests, missions and power. The development of cooperation and exchange program of Master or PhD by promoting joint programs.

Only in the last 10 years we have signed a series of mutual agreements of cooperation with other international universities. They are shown in the following map 1.

\section{Results}

The most important results of these collaborations are:

- The establishment and consolidation of faculties as well as the establishment of new programs study;

- Improvement of teaching infrastructure and laboratories in the different branches;

- Professional and scientific qualifications of the academic staff;

- Implementation of joint scientific projects in the framework of Tempus, CEEPUS, and Erasmus Mundus programs ect;

- Preparation and publication of scientific articles in common fields.

Conclusion

This experience has served as a basic academic and institutional value that will assist in fulfilment of our objectives in the university labour market;

- the adaptation of studies and students' graduation in order to make able to compete in the labour market;

- the continuity of studies in three cycles study;

- providing a higher level of students' training;

- adapting University of Shkodra offers to the demands and professional opportunities of the labour market;

- stimulation of the mobility (for students and academic staff) in national and international universities; 
- enhancing inter-institutional cooperation;

- integrated study programs focused on regional development;

- involvement in joint research projects among different universities.

Through this paper we emphasize that in the context of higher education reform, USH seeks to engage the best possible and sustainable alternative, in the area of Albanian higher education.

\section{References}

Haxhi A \& Beka I ( 2012) Declaration of Bologna and our integration into European Higher Education "Procceding : July,

4th annual International Conference on Education and New Learning Technologies Barcelona (Spain), 2- 5

Haxhi A \& Beka I ( 2010) Integrative Perspectives of the University of Shkodra "Luigj Gurakuqi" in the European Higher Education. Published in Turkey in the book with the title : The challenges of the Institutions of Higher Education in Balcan , ISBN 978374-134-7, 83-88.

Haxhi A, Beka I, Vadahi F \& Curcija E( 2010) "The Bologna Process and the University of Shkodra" speech held at the Conference titled:"The Bologna Process, commitments and experiences", Shkoder

Haxhi A , Beka I \& Vadahi F (2009)"Our challenges in integrating into European Higher Education"Scientific Bulletin of the University of Shkodra, Educational Science Series,59,pg.7-15

Haxhi A , Beka I \&Vadahi F( 2008)"Challenges of the University of Shkodra, as promoter of regional development and integration", Scientific Bulletin of the University of Shkodra, Educational Science Series, 58,.9-17

Beka I \& Shllaku N ( 2007 )"An integral part of the scientific cooperation strategy of the University of Shkodra ", Scientific Bulletin of the University of Shkodra, Educational Science Series,57, 27-35. Hoti M \& Beka I ( 2004) "University of Shkodra under the Bologna Process". Scientific Bulletin of the University of Shkodra, Educational Science Series, nr 54, 2004, pg 7-13.

Instruction of the Ministry of Education and Science on Bologna Declaration,2004

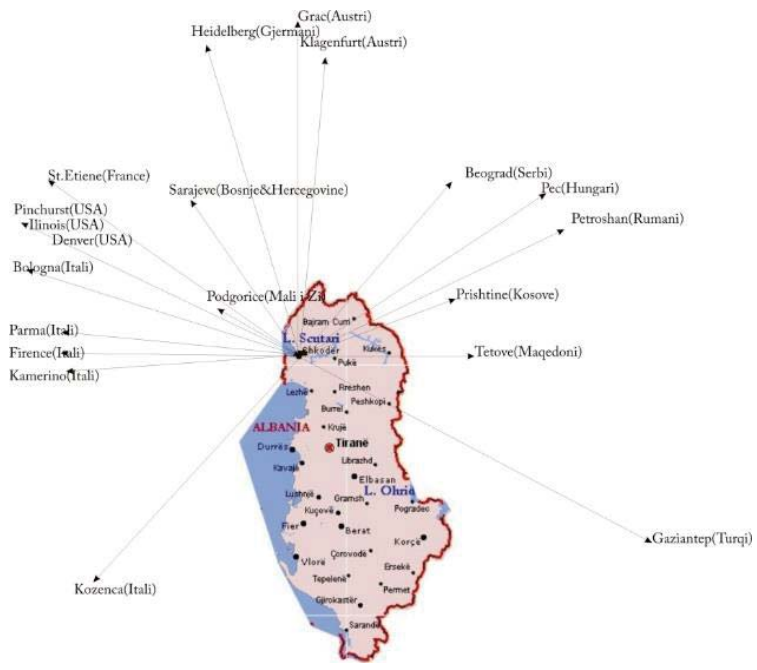

Fig.1 Map of collaboration of Shkodra university with foreing universities. 